\title{
Two Portuguese Cochlear Implanted Dizygotic Twins: A Case Report
}

\author{
Joana Rita Chora, ${ }^{1}$ Helena Simões-Teixeira, ${ }^{1}$ Tiago Daniel Matos, ${ }^{1}$ \\ Jorge Humberto Martins, ${ }^{2}$ Marisa Alves, ${ }^{2}$ Raquel Ferreira, ${ }^{2}$ Luís Silva, ${ }^{2}$ \\ Carlos Ribeiro, ${ }^{2}$ Graça Fialho, ${ }^{1}$ and Helena Caria ${ }^{1,3}$ \\ ${ }^{1}$ Center for Biodiversity, Functional and Integrative Genomics, Faculty of Science, University of Lisbon, 1749-016 Lisbon, Portugal \\ ${ }^{2}$ ENT Department, Centro Hospitalar de Coimbra, Quinta dos Vales 3041-801 S. Martinho do Bispo, Coimbra, Portugal \\ ${ }^{3}$ School of Health, Polytechnic Institute of Setúbal, Largo Defensores da República, 2910-470 Setúbal, Portugal
}

Correspondence should be addressed to Helena Caria, helena.caria@ess.ips.pt

Received 31 May 2012; Accepted 10 July 2012

Academic Editors: S.-C. Chae and A. DeWan

Copyright ( $) 2012$ Joana Rita Chora et al. This is an open access article distributed under the Creative Commons Attribution License, which permits unrestricted use, distribution, and reproduction in any medium, provided the original work is properly cited.

\begin{abstract}
Individual's hearing performance after cochlear implant (CI) is variable and depends on different factors such as etiology of deafness, age at implantation, and social/family hearing environment. Here we report the case of dizygotic twins, boy and girl, presenting with neurosensorial profound deafness prior CI (age of implantation $=3.5$ years old). Both parents have severe/profound deafness, since childhood, and use sign language as primary mode of communication. Clinical and genetic characterization was performed, as well as the assessment of the auditory and oral (re)habilitation after CI, applying a battery of audiological, speech, and language tests. The twin girl and the father were homozygous for the c.35delG mutation in the GJB2 gene, while the twin boy and the mother were compound heterozygotes, both monoallelic for c.35delG and for the deletion del(GJB6-D13S1830) in the GJB6 gene. The remaining hearing impaired relatives were c.35delG homozygotes. The genetic cause of deafness was thus identified in this family. Some noteworthy differences were observed regarding twins' auditory and oral performance after CI. Subsequent follow-up of these children allowed us to conclude that those differences were most likely due to the different environment in which the twins have been living than to their different GJB2/GJB6 genotypes.
\end{abstract}

\section{Introduction}

After cochlear implantation (CI) the individual's hearing performance will vary according to their age at implantation [1], duration of implant use [2], level of residual hearing and mode of communication [3]. However, it has been documented that the contribution of these factors to speech perception after CI explains less than $50 \%$ of the variability observed [4], the remaining being related to other factors. One of these factors is thought to be the etiology of deafness $[2,5,6]$, namely, connexin-associated deafness [7].

DFNB1 locus was the first nonsyndromic autosomal recessive deafness-related locus to be identified and is located on chromosome 13q11 [8]. It includes GJB2 and GJB6 genes, enconding the gap junction beta-2 protein (connexin 26 ) and the gap junction beta-6 protein (conexin 30), respectively. Mutations in the GJB2 gene are the most frequent in nonsyndromic recessive deafness, accounting for up to $50 \%$ of the cases [9]. The c.35delG mutation, a deletion of a guanine in the GJB2 coding sequence, is the most common recessive deafness-causing mutation in Europe. Two large deletions, $\operatorname{del}($ GJB6-D13S1830) and del(GJB6-D13S1854), identified in the GJB6 gene, are often found in double heterozygosity with mutations in GJB2, which is thought to result in loss of function of the connexin cluster [10]. Most of these genotypes originate severe to profound congenital deafness, which are the cases recommended for cochlear implantation.

This study aimed at performing clinical and genetic characterization, as well as evaluating the oral (re)habilitation, of two nonidentical twins with cochlear implant. 
TABLE 1: Clinical history of the twins.

\begin{tabular}{|c|c|c|}
\hline & ICC088 (III : 7) & ICC089 (III : 6) \\
\hline Gender & Female & Male \\
\hline Deafness etiology & Congenital & Congenital \\
\hline Suspicion of deafness & 18 months & 18 months \\
\hline Diagnosis & 24 months & 24 months \\
\hline Clinical history & $\begin{array}{l}\text { Normal pregnancy } \\
\text { No associated pathologies } \\
\text { No previous surgical procedures } \\
2 \text { episodes of ear infections (otitis) prior } \\
\text { implantation (without suppuration) } \\
\text { No allergies } \\
\text { Vaccination plan up to date }\end{array}$ & $\begin{array}{l}\text { Normal pregnancy } \\
\text { No associated pathologies } \\
\text { No previous surgical procedures } \\
\text { No allergies } \\
\text { Vaccination plan up to date }\end{array}$ \\
\hline Audiogram & $\begin{array}{l}\text { Neurosensorial bilateral profound deafness, } \\
\text { stage } 3\end{array}$ & $\begin{array}{l}\text { Neurosensorial bilateral profound deafness, } \\
\text { stage } 3\end{array}$ \\
\hline Placement of hearing aids & 24 months & 24 months \\
\hline Gain with hearing aids & $\begin{array}{l}\text { Very poor adaptation } \\
\text { No language development }\end{array}$ & $\begin{array}{l}\text { Good adaptation } \\
\text { Functional gain up to } 1000 \mathrm{~Hz} \\
\text { No language development }\end{array}$ \\
\hline Auditory evoked potentials (AEP) & $\begin{array}{l}\text { Wave V present above } 90 \mathrm{~dB} n H L \text { on the right } \\
\text { and above } 100 \mathrm{~dB} \mathrm{nHL} \text { on the left }\end{array}$ & Absence of AEPs until $110 \mathrm{~dB}$ nHL bilaterally \\
\hline $\begin{array}{l}\text { Computerized axial tomography scan } \\
\text { (CAT scan) }\end{array}$ & $\begin{array}{l}\text { Morphologically normal and permeable cochlea } \\
\text { Normal inner ear canals }\end{array}$ & $\begin{array}{l}\text { Morphologically normal and permeable cochlea } \\
\text { Normal inner ear canals }\end{array}$ \\
\hline Magnetic resonance imaging (MRI) & $\begin{array}{l}\text { No morphological alterations } \\
\text { No congenital malformations } \\
\text { No cochlear nerve atrophy } \\
\text { Normal cochleas }\end{array}$ & $\begin{array}{l}\text { No morphological alterations } \\
\text { No congenital malformations } \\
\text { No cochlear nerve atrophy } \\
\text { Normal cochleas }\end{array}$ \\
\hline Age at implantation & 42 months & 42 months \\
\hline Duration of CI use & 56 months & 56 months \\
\hline $\begin{array}{l}\text { Age at audiological tests and present } \\
\text { study }\end{array}$ & 8 years & 8 years \\
\hline CI model & CI24R CA Advance & CI24R CA Advance \\
\hline Speech processor & SPRINT & SPRINT \\
\hline Stimulation mode & $\mathrm{MP} 1+2$ & $\mathrm{MP} 1+2$ \\
\hline Stimulation strategy & ACE & ACE \\
\hline Implanted ear & Right & Right \\
\hline
\end{tabular}

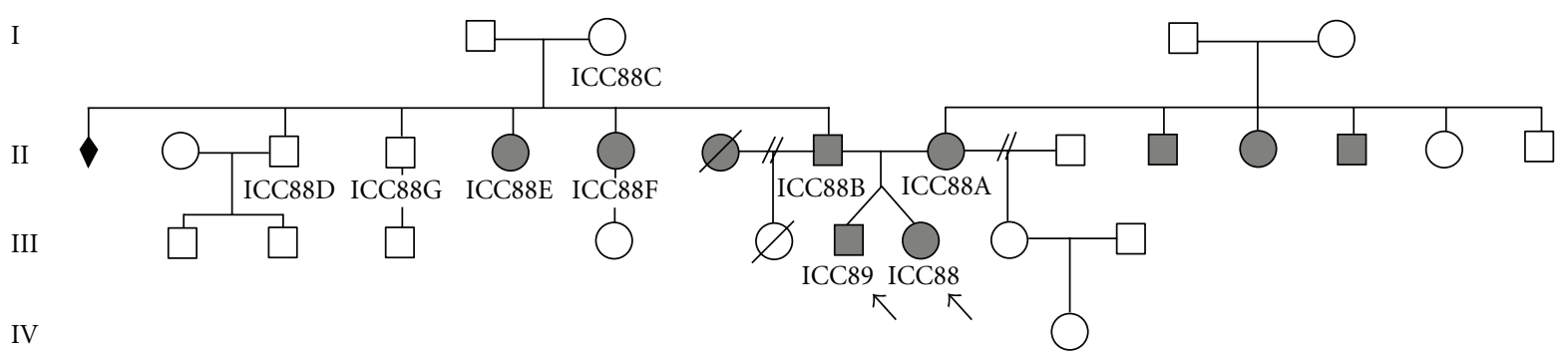

FIgURE 1: Family pedigree. Affected relatives are in full colour, the arrows signal the twins.

\section{Patient Presentation}

We report the case of dizygotic twins (a boy and a girl), aged 8 years, both with cochlear implants (CI). Both twins (Figure 1: ICC88, III:7 and ICC89, III:6) presented with neurosensorial profound hearing loss prior to implantation. Their parents (Figure 1: ICC88A, II: 9 and ICC88B, II: 8) are also severely to profoundly hearing impaired since childhood, use sign language as primary mode of communication, and have one unaffected daughter each, from a prior marriage, as well as several affected and unaffected relatives.

Table 1 presents the clinical history of the twins. It can be observed that both of them were diagnosed, started using hearing aids, and received their cochlear implant at the same 


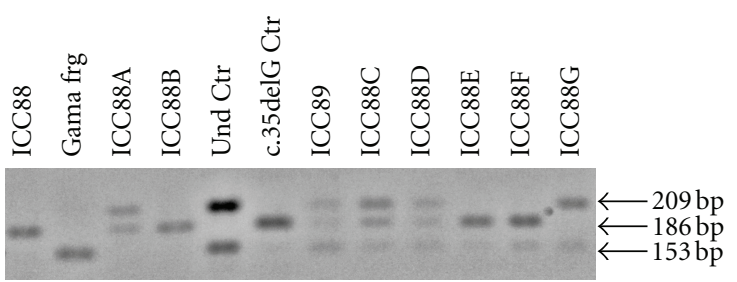

(a)

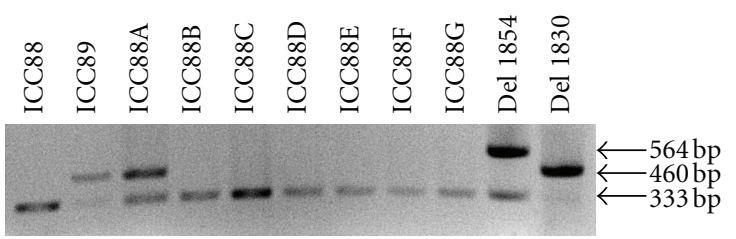

(b)

FIGURE 2: Electrophoresis results. (a) Enzymatic restriction with BslI for identification of c.35delG mutation according to Storm et al. [11]. Gama frg: internal restriction control (153bp band); Und Ctr: undigested restriction control (209 bp and 153 bp bands); c.35delG Ctr: c.35delG homozygous control (186 bp band). Homozygous mutated individuals present only the $186 \mathrm{bp}$ band and heterozygous individuals present both the $209 \mathrm{bp}$ and $186 \mathrm{bp}$ bands. (b) PCR multiplex for identification of $\operatorname{del}($ GJB6-D13S1830) and del(GJB6D13S1854) according to del Castillo et al. [10]. Del 1854: heterozygous control for del(GJB6-D13S1854); Del 1830: heterozygous control for $\operatorname{del}(G J B 6-\mathrm{D} 13 \mathrm{S1830})$. The $333 \mathrm{bp}$ band corresponds to nonmutated allele, the $460 \mathrm{bp}$ band to $\operatorname{del}($ GJB6-D13S1830) mutated allele and 564 bp band to del(GJB6-D13S1854) mutated allele.

time. Likewise, they use the same CI model with the same characteristics.

Written informed consent was obtained from all individuals and the study was approved by the Ethical Commission of the Hospital.

DNA from the two twins and from affected and unaffected relatives was analysed, by sequencing and multiplex PCR, in respect to the presence of GJB2 coding mutations and GJB6 deletions (del(GJB6-D13S1830) and $\operatorname{del}(G J B 6-$ D13S1854)). Molecular analysis revealed that the twins present different genotypes: the girl (ICC088, III:7) is homozygous for the c.35delG autosomal recessive mutation in GJB2 while the boy (ICC089, III : 6) is a compound heterozygote for the c.35delG mutation and the GJB6 large deletion $\operatorname{del}($ GJB6-D13S1830) (Figure 2). Both genotypes are associated with severe congenital deafness phenotype. This genetic evaluation was included in a broader study involving DFNB1 genotype-phenotype correlation in Portuguese CI individuals [7], being the first time that $\operatorname{del}($ GJB6-D13S1830) deletion was found in Portuguese deaf patients.

The different genotypes of the twins justified the genetic analysis of some of the twins' relatives (Figure 2). The father (ICC088B, II : 8) is a c.35delG homozygote, as the twin girl, and the mother (ICC088A, II:9) is a c.35delG/del(GJB6D13S1830) compound heterozygote like the twin boy. Accordingly, the affected relatives from the father's side (ICC088E, II : 5 and ICC088F, III :6) are c.35delG homozygotes and the unaffected relatives either present one

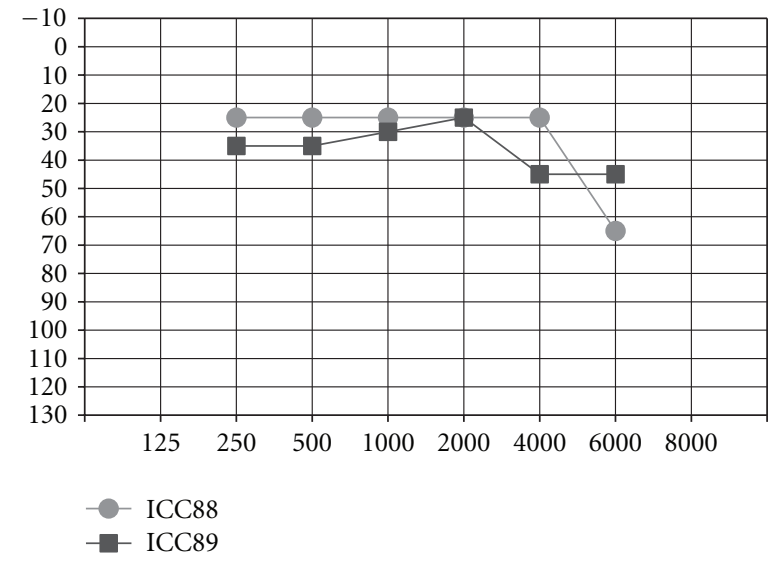

Figure 3: Pure-tone threshold levels of the twins after cochlear implantation (age 3, 5 years).

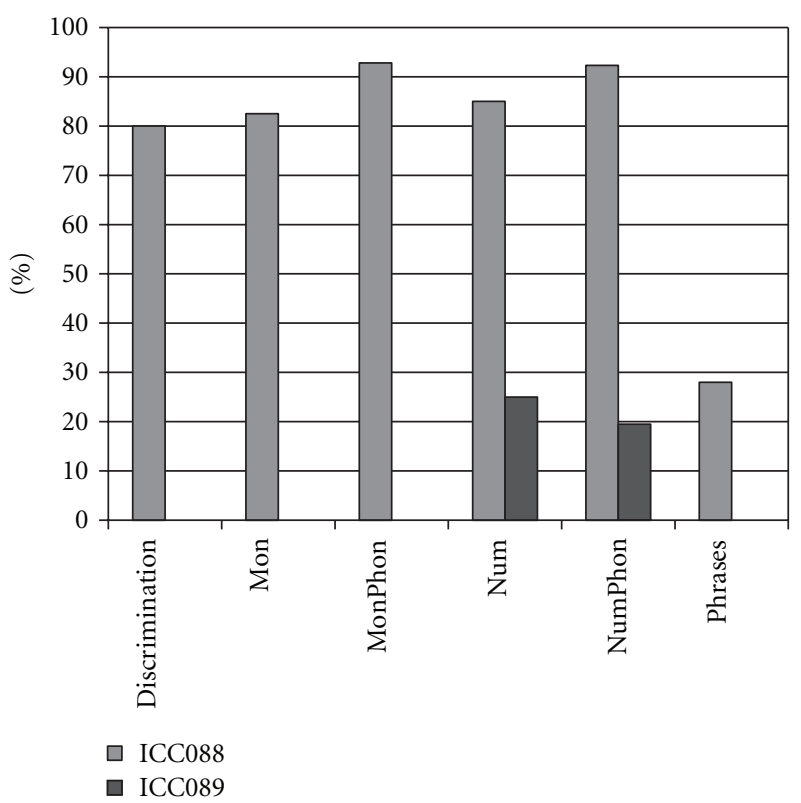

FIGURE 4: Twins speech perception tests results (taken in 2009, 5 years of implant use). Disyllabic words test discrimination score, Monosyllable test, Monosyllable phoneme test, Number test, Number phoneme test, and Phrases: sentences test.

(ICC088C, I: 2 and ICC088D, II :3) or none (ICC088G, II : 4) c.35delG alleles. None of them presented the GJB6 deletion. On the mother's side no relative has been studied.

Assessment of the twins' global auditory and oral performance after cochlear implantation was carried out by applying a battery of audiological, speech, and language tests at the ENT Department from the Centro Hospitalar de Coimbra such as disyllabic words test discrimination score, monosyllable test, monosyllable phoneme test, number test, number phoneme test, sentences test, categories auditory performance (CAP), closed-set word perception test (with real objects, images, or written words), verbal articulation test (evaluates 19 consonants and 3 consonant groups, calculated as percentage of phonemes correctly produced), 


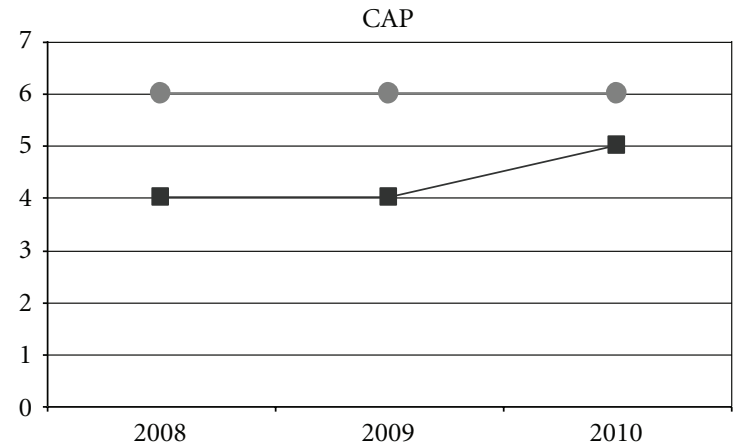

ICC 88

- ICC89

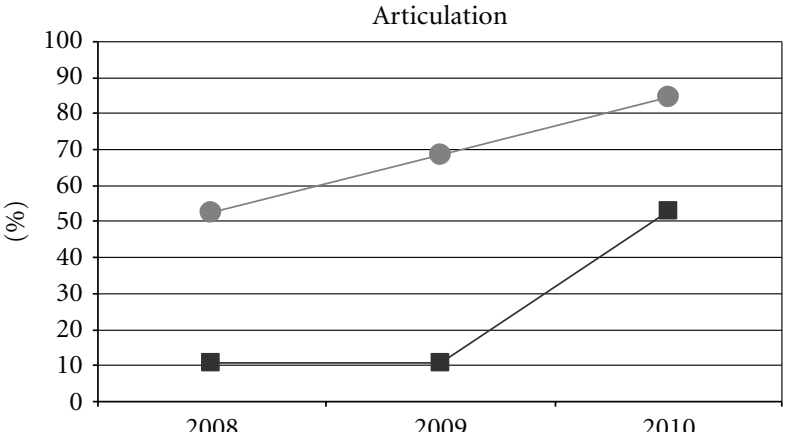

ICC 88

ICC89

(c)

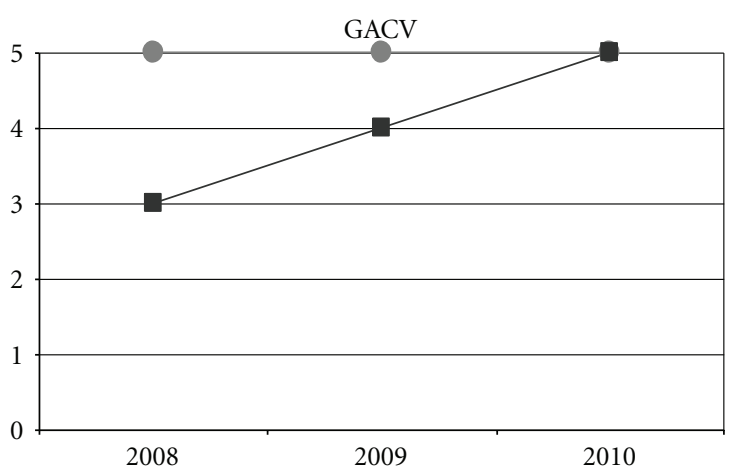

- ICC88

- ICC89

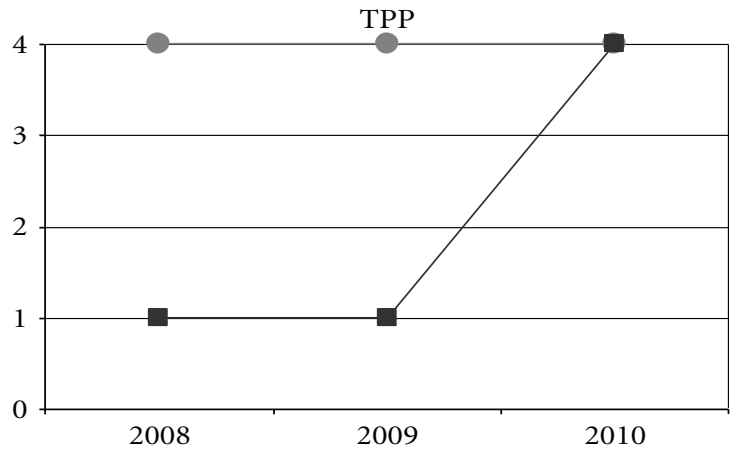

- ICC88

- ICC89

(b)

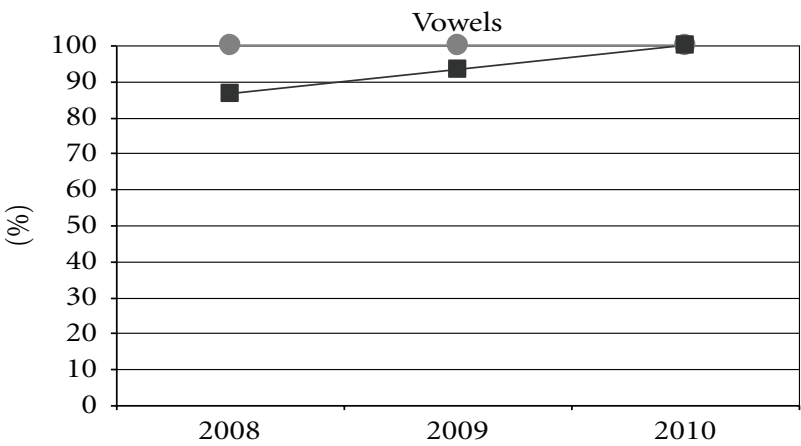

ICC88

ICC89

(d)

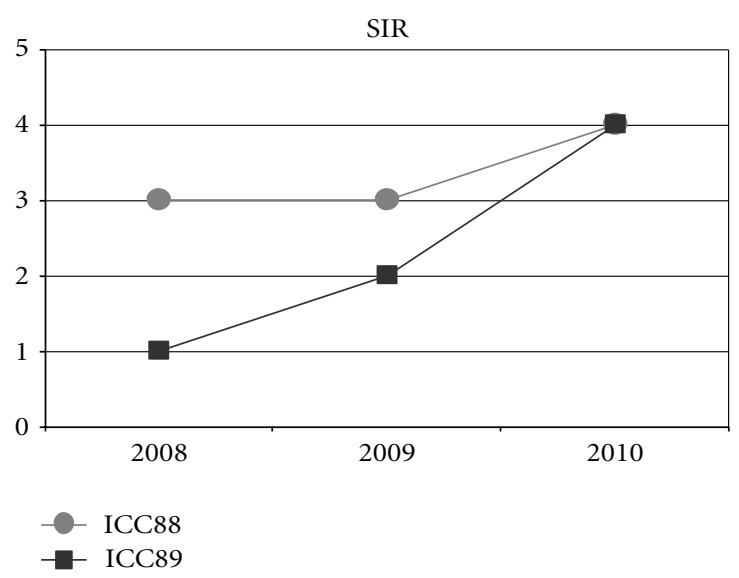

(f)

FIgure 5: Twins' audiological test results in the last three years. (a) CAP: Categories Auditory Performance; (b) TPP: closed-set word perception test; (c) Articulation: verbal articulation test; (d) Vowels: percentage of accurate vowels; (e) GACV: Vocal characteristics test (voice intensity, pitch, nasal resonance, intonation and breathing, etc.); (f) SIR: Speech Intelligibility Ratting.

percentage of accurate vowels, vocal characteristics test (voice intensity, pitch, nasal resonance, intonation and breathing, phonation and articulation coordination), and speech intelligibility rating (SIR).
When observing the twins' audiograms at 3.5 years old, just after CI, (Figure 3), the pure tone thresholds for most frequencies were very similar. Thus, it would be reasonable to assume their auditory and oral performance scores would 
also be similar. However the speech perception tests performed after 5 years of CI use (Figure 4), show that the twin girl (ICC88, III:7) had an overall good performance throughout the tests while the twin boy (ICC89, III:6) got poorer results, had difficulties regarding some of the age appropriate tests that are part of the standard evaluation, and was not even able to respond to some of the tests.

Could the differences in auditory and oral outcomes on post-CI rehabilitation be related to the different DFNB1 genotypes? Further analysis of the family history showed that other factors could be playing an important role and contributing for the differences observed. The twins had not lived together in the same hearing environment as previously assumed. On the contrary, each of them came from a different social background. The twin girl has lived since she was 6 months-old with their hearing aunt, and uncle (II: 1 and II :2) and has been educated in a regular school with special education and speech therapy while the twin boy lived until 7 years-old with the hearing impaired parents, who only used sign language as mode of communication, thus in a poor auditory stimulating environment, only having contact with other deaf children, and with some household problems. In 2009, through legal decision, he moved in with his sister, aunt and uncle (II : 1 and II :2) and integrated regular school with special education and speech therapy. The audiological tests from the last three years revealed the twin boy's favourable evolution since this social alteration (Figure 5 ). The positive effect of the auditory and oral stimulation observed in the twin since he moved to his aunt highlights the importance of the auditory stimulating environment in the success of the post-CI rehabilitation.

\section{Conclusion}

The nonidentical twins here analysed, aged 8 years-old presented different genotypes, c.[35delG]+[35delG] and [c.35delG]+[del(GJB6-D13S1830)], and different speech perception results after CI. The twin boy presented weaker verbal outcomes and worse level of residual hearing before he was implanted (absence of AEP's). However, both twins' audiograms were very alike after $\mathrm{CI}$, revealing that their hearing thresholds, unlike their auditory and oral performance, were similar.

As such, the observed differences in the oral performance are most likely due to the different social context in which the twins have been living and not to their different GJB2/GJB6 genotype. The oral outcome of the twin boy improved from the moment he started living in a hearing stimulating environment, which is a strong evidence of this factor's importance in the success of the oral rehabilitation after CI, namely, in DFNB1-associated hearing loss cases.

The remaining twins' affected relatives studied carried the c.35delG mutation in homozigosity. Molecular diagnosis and genetic counselling is thus very important to a family such as this one, namely, to the twins' unaffected half-sister still alive.

\section{Acknowledgments}

The authors would like to thank the family for their contribution to the investigation. The present study was financially supported by Cochlear.

\section{References}

[1] M. Manrique, F. J. Cervera-Paz, A. Huarte, and M. Molina, "Advantages of cochlear implantation in prelingual deaf children before 2 years of age when compared with later implantation," Laryngoscope, vol. 114, no. 8, pp. 1462-1469, 2004.

[2] S. S. Connell, S. I. Angeli, H. Suarez, A. V. Hodges, T. J. Balkany, and X. Z. Liu, "Performance after cochlear implantation in DFNB1 patients," Otolaryngology, vol. 137, no. 4, pp. 596-602, 2007.

[3] R. Taitelbaum-Swead, Z. Brownstein, C. Muchnik et al., "Connexin-associated deafness and speech perception outcome of cochlear implantation," Archives of Otolaryngology, vol. 132, no. 5, pp. 495-500, 2006.

[4] G. M. Clark, R. K. Shepherd, and C. G. Treaba, "Peri-modiolar electrode arrays: a comparison of electrode position in the human temporal bone," in Cochlear Implants: XVI World Congress of Otorhinolaryngology Head and Neck Surgery, pp. 205-209, Monduzzi Editore, Bologna, Italy, 1997.

[5] C. C. Morton and W. E. Nance, "Newborn hearing screening-a silent revolution," New England Journal of Medicine, vol. 354, no. 20, pp. 2151-2164, 2006.

[6] T. V. Christiani, F. Alexandrino, C. A. De Oliveira et al., "Molecular study in Brazilian cochlear implant recipients," American Journal of Medical Genetics, Part A, vol. 143, no. 14, pp. 1580-1582, 2007.

[7] J. R. G. D. B. M. Chora, T. D. M. Matos, J. H. F. Martins et al., "DFNB1-associated deafness in Portuguese cochlear implant users: prevalence and impact on oral outcome," International Journal of Pediatric Otorhinolaryngology, vol. 74, no. 10, pp. 1135-1139, 2010.

[8] P. Guilford, S. B. Arab, S. Blanchard et al., "A non-syndromic form of neurosensory, recessive deafness maps to the pericentromeric region of chromosome 13q," Nature Genetics, vol. 6, no. 1, pp. 24-28, 1994.

[9] R. L. Snoeckx, P. L. M. Huygen, D. Feldman, S. Marlin, F. Denoyelle, J. Waligora et al., "GJB2 mutations and degree of hearing loss: a multicenter study," The American Journal of Human Genetics, vol. 77, pp. 945-957, 2005.

[10] F. J. Del Castillo, M. Rodríguez-Ballesteros, A. Álvarez et al., "A novel deletion involving the connexin-30 gene, $\operatorname{del}(G J B 6-$ d13s1854), found in trans with mutations in the GJB2 gene (connexin-26) in subjects with DFNB1 non-syndromic hearing impairment," Journal of Medical Genetics, vol. 42, no. 7, pp. 588-594, 2005.

[11] K. Storm, S. Willocx, K. Flothmann, and G. Van Camp, "Determination of the carrier frequency of the common GJB2 (connexin-26) 35delG mutation in the Belgian population using an easy and reliable screening method," Human Mutation, vol. 14, no. 3, pp. 263-266, 1999. 


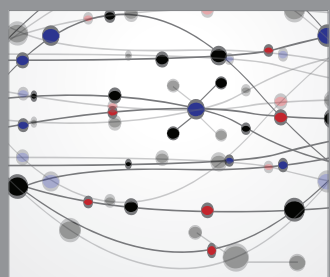

The Scientific World Journal
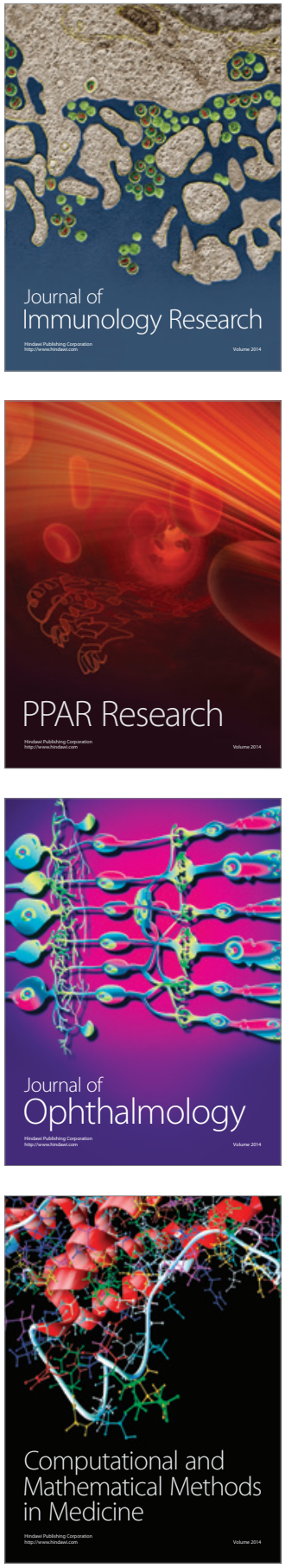

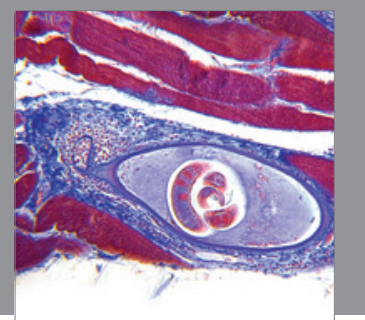

Gastroenterology

Research and Practice
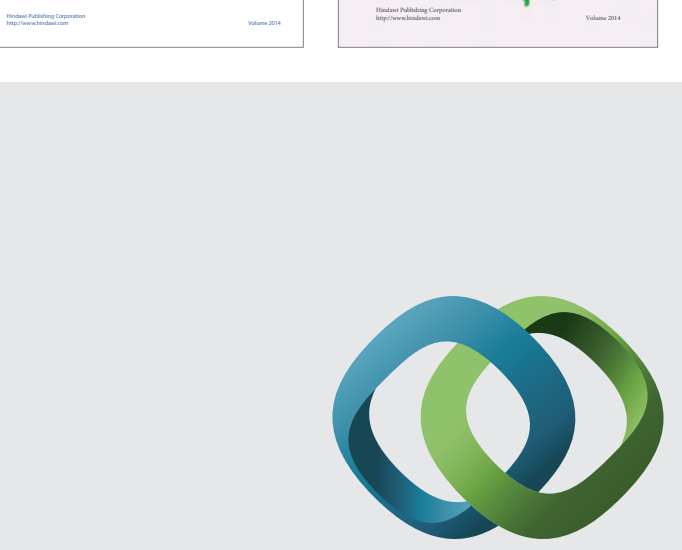

\section{Hindawi}

Submit your manuscripts at

http://www.hindawi.com
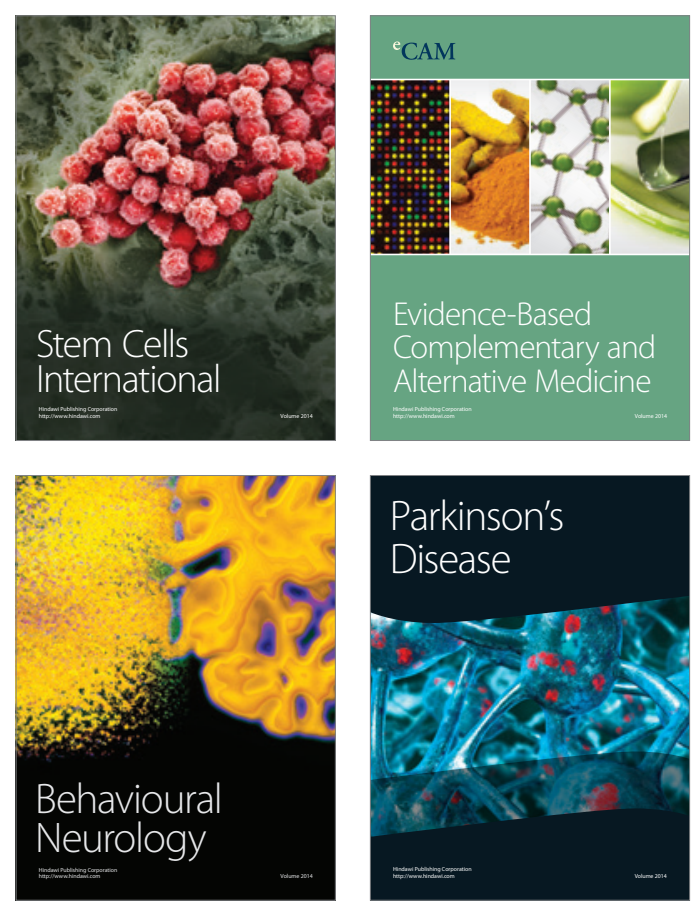

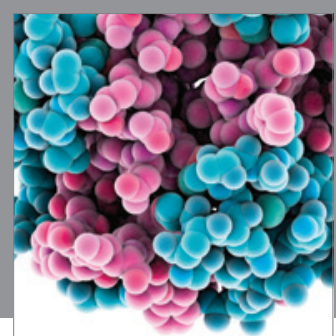

Journal of
Diabetes Research

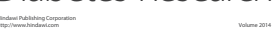

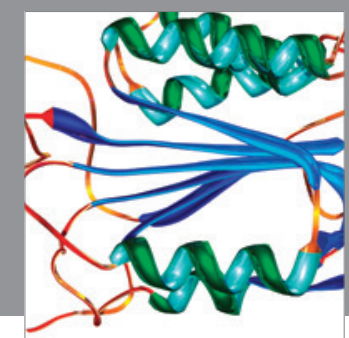

Disease Markers
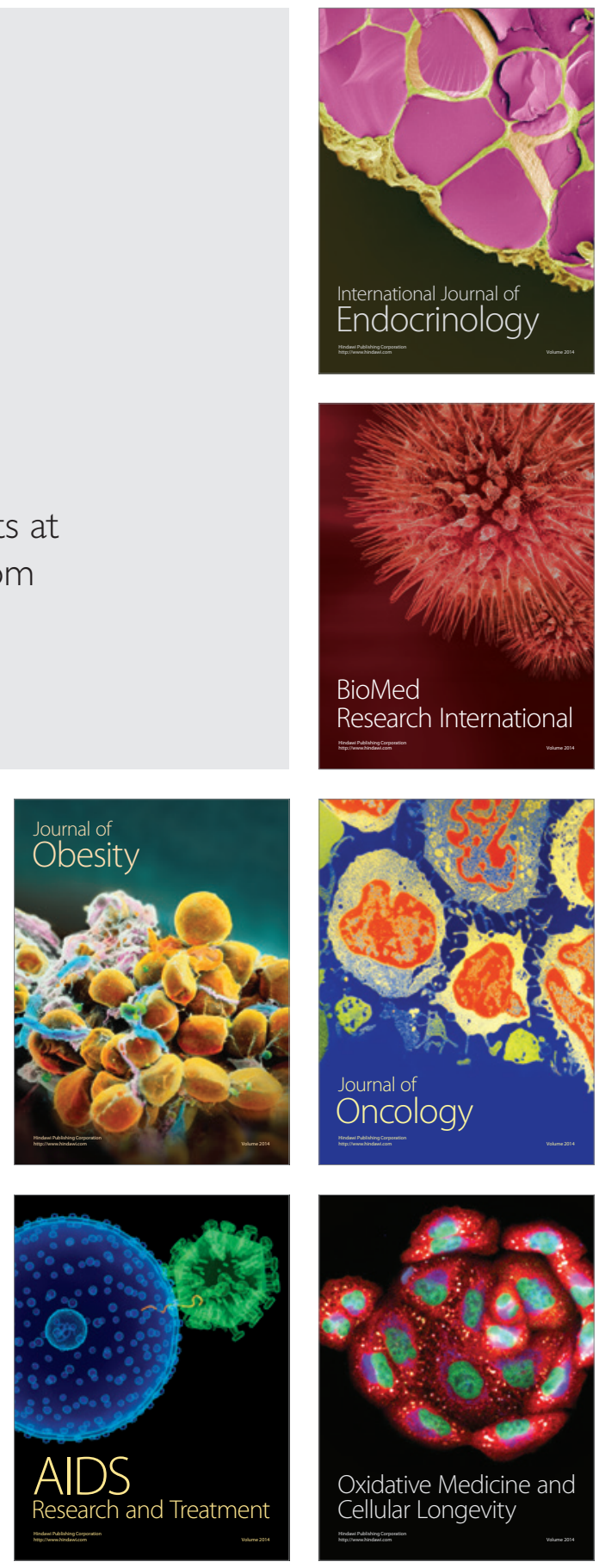